\title{
KENDALA KEUANGAN DAN SALING KETERGANTUNGAN DALAM KEPUTUSAN KEUANGAN PADA SEKTOR CONSUMER GOODS DI INDONESIA
}

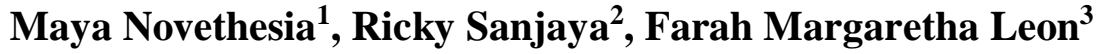 \\ ${ }^{1}$ Magister Manajemen, Universitas Trisaksi Jakarta \\ Email: novethesia@gmail.com \\ ${ }^{2}$ Magister Manajemen, Universitas Trisaksi Jakarta \\ Email: rickysanjaya1994@gmail.com \\ ${ }^{3}$ Dosen Fakultas Ekonomi dan Bisnis, Universitas Trisakti Jakarta \\ Email: farahmargaretha@trisaktiac.id
}

Masuk : 07-05-2020, revisi: 30-05-2020, diterima untuk diterbitkan : 31-05-2020

\begin{abstract}
ABSTRAK
Penelitian ini dilakukan untuk menguji kendala keuangan dan saling ketergantungan dalam keputusan keuangan. Sampel yang digunakan dalam penelitian ini adalah perusahaan pada sektor consumer goods yang go public dan terdaftar di Bursa Efek Indonesia (BEI) periode 2014-2018. Terdapat 24 perusahaan swasta yang dapat diteliti setelah dilakukan purposive sampling. Arus kas sebagai variabel dependen yang diukur dengan pengeluaran modal, perubahan kas, dividen, perubahan hutang jangka pendek dan panjang dan total aset. Investasi, kas, dan hutang sebagai variabel independen yang diukur menggunakan aktiva tetap bersih, kas, hutang jangka pendek dan panjang, perubahan dalam modal kerja, dividen, nilai pasar dan total aset. Sedangkan arus kas perusahaan dan resiko operasional perusahaan sebagai variabel moderasi. Penelitian ini menggunakan metode least square dan uji individu (uji-t). Hasil penelitian ini menunjukkan bahwa investasi, kas, dan hutang berpengaruh positif terhadap arus kas perusahaan. Implikasi dari penelitian ini bagi manajer keuangan agar perlu memperhatikan jumlah hutang perusahaan karena sangat berpengaruh terhadap arus kas perusahaan. Bagi peneliti selanjutnya sebaiknya menggunakan perusahaan pada sektor lain.
\end{abstract}

Kata Kunci: Investasi, Kas, Hutang, Arus Kas, Aset, Consumer Goods.

\section{ABSTRACT}

This research was conducted to support finance and interdependence in financial decisions. The sample used in this study was companies in the consumer goods sector that went public and were listed on the Indonesia Stock Exchange (IDX) for the 2014-2018 period. There are 24 companies that can be issued after purposive sampling. Cash flow as the dependent variable needed with capital, cash changes, dividends, short-term loans and total assets. Investment, cash, and debt as independent variables using fixed bonds, cash, short and long term loans, changes in working capital, dividends, market value and total assets. While the company's cash flow and company operational risk as a moderating variable. This research uses the quadratic method and individual test (t-test). The results of this study prove that investment, cash, and loans are positive towards the company's cash flow. The implications of this study for financial managers need to be considered by the number of companies because they need to be considered for the company's cash flow. For further researchers need to use companies in other sectors.

Keywords: Investation, Cash, Debt, Cash Flow, Consumer Goods.

\section{PENDAHULUAN}

\section{Latar Belakang}

Ekonomi global yang terus maju akan menimbulkan persaingan usaha atau bisnis yang semakin ketat karenanya para manajer perusahaan harus meningkatkan produktivitas kegiatan produksi atau operasional, pemasaran, serta strategi perusahaan. Kegiatan tersebut berkaitan dengan usaha perusahaan untuk memaksimalkan laba atau keuntungan di persaingan ekonomi global yang sangat ketat ini. Namun bukan hanya berorientasi pada pencapaian laba yang maksimal, tetapi perusahaan juga harus meningkatkan nilai perusahaan dan kemakmuran pemiliknya serta pemegang saham. Maka dari itu, perusahaan harus memiliki rencana yang strategis yang disusun untuk pencapaian tujuan yang telah ditetapkan. Untuk memenuhi tujuan perusahaan tersebut, 
maka diperlukan pengambilan keputusan yang tepat dari para manajer perusahaan baik keputusan investasi, keputusan pendanaan maupun keputusan deviden. Dalam melakukan kegiatan usaha ekonomi, salah satu faktor produksi yang perlu disediakan para pelaku bisnis adalah ketersediaan modal. Modal adakalanya berasal dari internal perusahaan, maupun eksternal perusahaan. Untuk mendapatkan modal eksternal, berbagai cara dapat dilakukan, diantaranya melalui lembaga keuangan pasar modal.

Dong, Ming., D. H. dan S. H. T. (2015) meyatakan bahwa perusahaan yang sukses dalam bisnis harus baik dalam pengelolaan keuangan. Ini berarti bahwa setiap perusahaan harus membuat keputusan investasi yang baik dan keputusan pendanaan yang baik. Keputusan investasi dan pendanaan yang unggul dapat membawa perusahaan selangkah lebih maju dari para pesaing mereka. Sekumpulan keputusan investasi atau pendanaan yang buruk akan mengakibatkan kerusakan yang parah. Dong, Ming., D. H. dan S. H. T. (2015) berpendapat bahwa perusahaan yang sedang berkembang membutuhkan modal yang dapat berasal dari hutang maupun ekuitas. Dalam persaingan yang ketat ini, perusahaan harus memiliki pendanaan yang tepat, dimana perlu adanya peran manajer dalam menentukan struktur modal yang paling optimal. Dong, Ming., D. H. dan S. H. T. (2015) menjelaskan struktur modal yang optimal adalah struktur modal yang memaksimumkan harga saham perusahaan, dan ini memerlukan rasio utang yang lebih rendah daripada rasio hutang yang memaksimumkan EPS. Sedangkan menurut Agliardi, E., Agliardi, R., \& Spanjers, W. (2016) struktur modal yang optimal dari perusahaan akan mampu meminimalkan biaya modal yang harus ditanggung oleh perusahaan. Struktur modal menjadi masalah yang penting bagi perusahaan karena baik buruknya struktur modal akan mempengaruhi kondisi keuangan perusahaan yang pada akhirnya berpengaruh juga terhadap nilai perusahaan. Maka dari itu, manajemen dalam menetapkan struktur modal tidak bersifat mengekang namun disesuaikan dengan keadaan perusahaan sehingga tujuan manajer untuk memaksimumkan kemakmuran para pemegang saham dapat terwujud.

Menurut teori MM (Modigliani-Miller) dengan efek pajak, penggunaan hutang dapat menyebabkan nilai suatu perusahaan meningkat, meskipun faktanya pengaruh hutang terhadap harga saham sulit untuk diketahui. Penggunaan hutang memiliki keuntungan dan kelemahan. Keuntungan dari penggunaan hutang yaitu bunga yang dibayarkan dapat mengurangi pajak yang dibayarkan sehingga mampu menurunkan biaya efektif dari hutang. Kemudian kelemahannya adalah semakin tinggi penggunaan hutang, maka semakin tinggi pula tingkat resiko yang akan dihadapi oleh perusahaan. Dan apabila kondisi ekonomi yang melemah seperti sekarang ini, terdapat kemungkinan perusahaan mengalami kesulitan keuangan yang semakin besar, dan jika laba operasi tidak mampu menutupi beban bunga, maka para pemegang sahamlah yang harus menutupi kekurangannya, dan perusahaan akan mengalami kebangkrutan jika tidak mampu untuk membayarnya (Dong, Ming., D. H. dan S. H. T., 2015). Penting bagi suatu perusahaan untuk mempertimbangkan variabel-variabel yang mempengaruhi struktur modal sehingga dapat menetapkan keputusan struktur modal yang tepat, serta dapat membantu pihak manajemen untuk menentukan pemenuhan dana untuk mencapai struktur modal yang optimum.

Penelitian ini menggunakan objek perusahaan pada sektor Consumer Goods yang terdaftar di Bursa Efek Indonesia dengan alasan jumlah barang konsumsi yang relatif stabil dan tidak banyak dipengaruhi oleh situasi perekonomian negara. Hal ini dikarenakan barang konsumsi termasuk barang kebutuhan sehari-hari atau bahkan kebutuhan primer. Maka dari itu, penjualan yang relatif stabil akan mampu memberikan laba yang lebih besar dan perusahaan dapat lebih banyak membiayai proses operasionalnya dengan dana tersebut. Analis PT Pemeringkat Efek Indonesia (Pefindo), Ahmad Sujatmiko mengatakan hampir semua sektor terkena dampak dari Indeks 
Harga Saham Gabungan (IHSG) yang terperosok dalam hingga level 5.108, tapi sektor consumer goods dan ritel yang masih bagus pada saat indeks anjlok saat ini. Agliardi, E., Agliardi, R., \& Spanjers, W. (2016) menyatakan perusahaan yang bangkrut mempunyai biaya hukum dan akuntansi yang sangat tinggi, dan mereka juga sulit untuk menahan pelanggan, pemasok, dan karyawan. Manajemen perusahaan sangat berperan penting dalam mengelola dana dengan lingkungan usaha perusahaan, kondisi keuangan perusahaan merupakan cermin baik buruknya manajemen suatu perusahaan.

Berdasarkan latar belakang di atas dan penelitian terdahulu, dilakukan penelitian di Indonesia dengan tujuan untuk mengetahui seberapa sensitif investasi terhadap arus kas berpengaruh untuk perusahaan yang mengalami kendala keuangan, untuk mengetahui seberapa sensitif kas terhadap arus kas untuk perusahaan yang mengalami kendala keuangan, dan untuk mengetahui seberapa sensitif hutang terhadap arus kas untuk perusahaan yang mengalami kendala keuangan. Oleh karena itu, Penelitian ini berjudul "Kendala Keuangan dan Saling Ketergantungan dalam Keputusan Keuangan pada Sektor Consumer Goods di Indonesia".

\section{Rumusan Masalah}

1. Apakah sensitivitas investasi terhadap arus kas berpengaruh positif?

2. Apakah sensitivitas arus kas terhadap kas berpengaruh positif?

3. Apakah sensitivitas hutang terhadap arus kas berpengaruh positif?

\section{METODE PENELITIAN}

\section{Metode Pengambilan Sampel}

Metode pengumpulan data yang digunakan adalah pengumpulan data sekunder, dimana data sekunder merupakan data yang diperoleh penelitian secara tidak langsung atau sumber yang telah dipublikasikan sehingga data tersebut telah tersedia. Sumber data pada penelitian ini diperoleh dari website Bursa Efek Indonesia (www.idx.co.id) dan website Badan Pusat Statistik (www.bps.go.id). Data penelitian ini terdiri dari semua perusahaan sektor consumer goods yang terdaftar di Bursa Efek Indonesia (BEI) selama periode 2014-2018.

Metode penarikan sampel yang dilakukan dalam penelitian ini dengan cara purposive sampling, dari metode tersebut didapatkan sampel penelitian sebanyak 24 perusahaan pada sektor consumer goods yang telah memenuhi kriteria tertentu:

Tabel 1. Kriteria Penarikan Sampel

\begin{tabular}{lc}
\hline \multicolumn{1}{c}{ Keterangan } & Jumlah \\
\hline $\begin{array}{l}\text { Perusahaan consumer goods yang telah go public dan terdaftar di Bursa Efek } \\
\text { Indonesia (BEI) }\end{array}$ & 56 \\
\hline $\begin{array}{l}\text { Perusahaan consumer goods yang telah go public dan tetrdaftar di Bursa Efek } \\
\text { Indonesia (BEI) untuk periode 2014-2018 }\end{array}$ & $(11)$ \\
\hline $\begin{array}{l}\text { Perusahaan consumer goods yang memiliki laporan keuangan lengkap pada } \\
\text { periode 2014-2018 }\end{array}$ & $(7)$ \\
\hline $\begin{array}{l}\text { Perusahaan consumer goods yang telah go public dan membayarkan dividen } \\
\text { periode 2014-2018 }\end{array}$ & 24 \\
\hline Total sampel yang dapat digunakan
\end{tabular}




\section{Identifikasi dan Pengukuran Variabel}

Identifikasi variabel pada penelitian ini yaitu untuk mengetahui hubungan antara variabel independen dan variabel moderasi terhadap variabel dependen, yang masing-masing variabel pengukurannya sebagai berikut:

Tabel 2. Definisi Operasional Variabel

\begin{tabular}{|c|c|c|}
\hline Jenis Variabel & Nama Variabel & $\begin{array}{r}\text { Pengukuran } \\
\end{array}$ \\
\hline \multirow{4}{*}{$\begin{array}{l}\text { Variabel } \\
\text { Dependen }\end{array}$} & Investment in physical capital & Pengeluaran modal/Total asset \\
\hline & Changes in cash holdings & Perubahan kas/Total asset \\
\hline & Dividends & Dividen/Total asset \\
\hline & Change in debt & $\begin{array}{l}\text { Perubahan hutang jangka pendek dan } \\
\text { panjang/Total aset }\end{array}$ \\
\hline \multirow{8}{*}{$\begin{array}{l}\text { Variabel } \\
\text { Independen }\end{array}$} & Capital stock & Aktiva tetap bersih/Total asset \\
\hline & Cash holdings & Kas/Total asset \\
\hline & $\begin{array}{l}\text { Dividends paid the previous } \\
\text { year }\end{array}$ & $\begin{array}{l}\text { Dividen tahun sebelumnya/Total asset } \\
\text { tahun sebelumnya }\end{array}$ \\
\hline & Debt stock & $\begin{array}{l}\text { Hutang jangka pendek dan } \\
\text { panjang/Total aset }\end{array}$ \\
\hline & Changes in net working capital & $\begin{array}{l}\text { Perubahan dalam (Aktiva lancer-Kas- } \\
\text { Kewajiban lancar-Hutang jangka } \\
\text { pendek)/Total aset }\end{array}$ \\
\hline & Firm size & Log alami dari total aset \\
\hline & $\begin{array}{l}\text { Cash flow generated over the } \\
\text { period }\end{array}$ & (Penghasilan+Depresiasi)/Total asset \\
\hline & $\begin{array}{l}\text { Recoverable fiction of firm's } \\
\text { asset }\end{array}$ & $\begin{array}{l}\text { (Kas+Piutang+Inventaris+Aktiva tetap } \\
\text { bersih)/Total asset x EffDebtEnforc }\end{array}$ \\
\hline \multirow{2}{*}{$\begin{array}{l}\text { Variabel } \\
\text { Moderasi }\end{array}$} & Firm's cash flows & (Penghasilan+Depresiasi)/Total asset \\
\hline & Firm's operational risk & ROA standar deviasi \\
\hline
\end{tabular}

\section{Model Penelitian}

Bagian ini menyajikan model empiris yang digunakan untuk menguji hipotesis penelitian, menjelaskan proses estimasi dan, akhirnya, merinci prosedur pemilihan sampel dan klasifikasi apriori perusahaan yang mengalami kendala finansial atau tidak mengalami kendala keuangan. Model empiris dan prosedur estimasi seperti dikutip oleh Mueller (1967), pemahaman menyeluruh tentang keputusan perusahaan hanya dapat dicapai dengan secara eksplisit mengakui berbagai interaksi yang dihasilkan dari simultanitas diantara keputusannya.

$$
\begin{aligned}
I_{i, t}= & \alpha_{0 i}+\alpha_{1} \Delta \text { Cash }_{i, t}+\alpha_{2} \text { Div }_{i, t}+\alpha_{3} \Delta \text { Debt }_{i, t}+\alpha_{4} \Delta N W C_{i, t}+\alpha_{5} K_{i, t-1}+\alpha_{6} Q_{i, t-1} \\
& +\alpha_{7} C F_{i, t}+\alpha_{8} R F A_{i, t}+\alpha_{9}\left(C F_{i, t} \times R F A_{i, t}\right)+\mu_{t}+\varepsilon_{i, t}^{I} \\
\Delta \text { Cash }_{i, t}= & \beta_{0 i}+\beta_{1} I_{i, t}+\beta_{2} \text { Div }_{i, t}+\beta_{3} \Delta \text { Debt }_{i, t}+\beta_{4} \Delta N W C_{i, t}+\beta_{5} \text { Cash }_{i, t-1}+\beta_{6} \text { Size }_{i, t} \\
& +\beta_{7} Q_{i, t}+\beta_{8} C F_{i, t}+\beta_{9}\left(\text { CF }_{i, t} \times H N_{i}\right)+\eta_{t}+\varepsilon_{i, t}^{\Delta C a s h}
\end{aligned}
$$




$$
\begin{aligned}
\text { Div }_{i, t}= & \gamma_{0 i}+\gamma_{1} I_{i, t}+\gamma_{2} \Delta \text { Cash }_{i, t}+\gamma_{3} \Delta \text { Debt }_{i, t}+\gamma_{4} \Delta N W C_{i, t}+\gamma_{5} \text { Div }_{i, t-1}+\gamma_{6} \text { Size }_{i, t} \\
& +\gamma_{7} Q_{i, t}+\gamma_{8} C F_{i, t}+\tau_{t}+\varepsilon_{i, t}^{D i v} \\
\Delta \text { Debt }_{i, t}= & \pi_{0 i}+\pi_{1} I_{i, t}+\pi_{2} \Delta \text { Cash }_{i, t}+\pi_{3} \text { Div }_{i, t}+\pi_{4} \Delta N W C_{i, t}+\pi_{5} \text { Debt }_{i, t-1}+\pi_{6} \text { Size }_{i, t} \\
& +\pi_{7} Q_{i, t}+\pi_{8} C F_{i, t}+\pi_{9}\left(\text { CF }_{i, t} \times H N_{i}\right)+\pi_{10} \text { RFA }_{i, t}+\pi_{10} \text { Risk }_{i, t}+\kappa_{t}+\varepsilon_{i, t}^{\Delta D e b t}
\end{aligned}
$$

\section{Metode Analisa Data}

Untuk menganalisis pengaruh investasi, kas dan hutang terhadap arus kas menggunakan analisa regresi data panel dengan program Eviews versi 11. Eviews (Econometric Views) merupakan aplikasi pengolahan data statistika dan ekonometrika yang berjalan diatas sistem Operasi Windows. Model default Eviews adalah Common Effect Model (CE).

\section{- Model Analisis Regresi:}

Arus Kas it $=\mathrm{a}+\mathrm{b} 1$ investasi it $+\mathrm{b} 2$ kas it $+\mathrm{b} 3$ utang it $\mathrm{e}$

Keterangan:

$\mathrm{Y}=$ Arus Kas

$\mathrm{X}_{1}=$ Investasi

$\mathrm{X}_{2}=\mathrm{Kas}$

$\mathrm{X}_{3}=$ Hutang

$\mathrm{a}=$ Konstanta (Intercept)

b1, b2, b3, b4, dan b5 = Koefisien Regresi (Slope)

$\mathrm{e}=$ error term

Kita dapat menggunakan Eviews untuk melakukan analisis cross section dan panel data serta melakukan estimasi dan peramalan data time series. Secara umum, Eviews 8 diklasifikasikan menjadi 4 (empat) bagian/tahapan. Bagian Pertama menerangkan Pendahuluan (Persiapan/Input Data), yang isinya bagaimana format penyusunan data untuk keperluan input data ke dalam software Eviews 8. Setelah itu, dilanjutkan dengan input data panel ke dalam software Eviews 8 yang prosedurnya relatif panjang. Bagian Kedua menjelaskan cara melakukan estimasi (pembuatan) model regresi data panel yang terdiri dari Common Effect $(C E)$, Fixed Effect $(F E)$, dan Random Effect $(R E)$.

\section{- Common Effect Model (CEM)}

CEM mengasumsikan tidak ada perbedaan efek sektor maupun waktu, sehingga dalam pemodelannya hanya terdapat satu model untuk seluruh pengamatan. Teknik estimasi CEM yaitu Ordinary Least Squares (OLS) (Falah et al., 2016).

\section{- $\quad$ Fixed Effect Model (FEM)}

FEM mengasumsikan bahwa antar unit sektor ataupun antar unit waktu memberikan efek yang berbeda terhadap model. Efek yang berbeda tersebut diperlihatkan pada nilai koefisien intersep (Falah et al., 2016).

\section{- Random Effect Model (REM)}

$R E M$ mengasumsikan bahwa terdapat efek sektor ataupun efek waktu yang dimasukkan dalam komponen residual model REM. Residual tersebut tidak berkorelasi dengan variabel dependen (Falah et al., 2016). Setelah kita mengetahui bagaimana melakukan estimasi model, maka bagian ketiga adalah memilih model regresi data panel yang paling 
tepat untuk tujuan penelitian. Bagian keempat, perbaikan terhadap adanya kasus heteroskedastisitas. Tahap awal dalam pendahuluan adalah mempersiapkan data. Data panel adalah data yang memiliki karakteristik cross section dan time series secara bersamaan. Dalam software Eviews, estimasi model/persamaan (Equation Estimation) dilakukan dengan cara memunculkan jendela Equation Estimation, lalu menuliskan persamaan/model yang akan diestimasi dalam jendela Equation Estimation. Dari ketiga model yang telah diestimasi akan dipilih model mana yang paling tepat/sesuai dengan tujuan penelitian. Ada tiga uji (test) yang dapat dijadikan alat dalam memilih model regresi data panel ( $C E, F E$ atau $R E$ ) berdasarkan karakteristik data yang dimiliki, yaitu: $\mathrm{F}$ Test (Chow Test), Hausman Test, dan Langrangge Multiplier (LM) Test.

\section{- Chow Test}

Chow Test (Uji Chow) yakni pengujian untuk menentukan model common effet atau fixed effect yang paling tepat digunakan untuk mengestimasi model regresi dari data yang tersedia. Hipotesis dalam uji Chow adalah:

$\mathrm{H}_{0} \quad$ : Common Effect Model atau pooled OLS

$\mathrm{H}_{\mathrm{a}} \quad$ : Fixed Effect Model

Dasar penolakan terhadap hipotesis di atas adalah dengan membandingkan perhitungan F-statistik dengan $\mathrm{F}_{\text {tabel, } \alpha=5 \%}$. Perbandingan dipakai apabila hasil $\mathrm{F}$ hitung lebih besar (>) dari $\mathrm{F}_{\text {tabel, } \alpha=5 \%}$ maka $\mathrm{H} 0$ ditolak yang berarti model yang paling tepat digunakan adalah Fixed Effect Model.

\section{- Hausman Test}

Hausman Test (Uji Hausman) yakni pengujian untuk menentukan model fixed effect atau random effect yang paling tepat digunakan untuk mengestimasi model regresi dari data yang tersedia. Hipotesis dalam Uji Hausman adalah:

$$
\begin{array}{ll}
\mathrm{H}_{0} & : \text { Fixed Effect Model } \\
\mathrm{H}_{\mathrm{a}} & : \text { Random Effect Model }
\end{array}
$$

Uji Hausman atau yang sering disebut dengan istilah Hausman Test adalah uji yang digunakan untuk menentukan metode yang terbaik antara fixed effect ataukah random effect. Dalam kesempatan ini akan kita bahas bagaimana cara melakukan Hausman Test dengan Eviews dalam regresi data panel. Hausman Test dengan Eviews sebenarnya sangatlah mudah untuk dilakukan. Syaratnya adalah kita harus melakukan langkah secara berurutan, yaitu melakukan analisis fixed effect terlebih dahulu kemudian dilanjutkan random effect.

\section{- Lagrange-Multiplier Test (LM)}

LM Test yakni pengujian untuk menentukan model fixed effect atau random effect yang paling tepat digunakan untuk mengestimasi model regresi dari data yang tersedia. Hipotesis dalam Uji Hausman adalah:

$\mathrm{H}_{0}$ : Common Effect Model

$\mathrm{H}_{\mathrm{a}} \quad$ :Random Effect Model

Lagrange Multiplier ( $L-M$ ) adalah uji untuk mengetahui apakah model random effect atau model common effect yang paling tepat untuk digunakan. Uji signifikasi random effect ini dikembangkan oleh Breusch Pagan. Metode Breusch Pagan untuk uji signifikasi random effect didasarkan pada nilai residu dari metode OLS. 


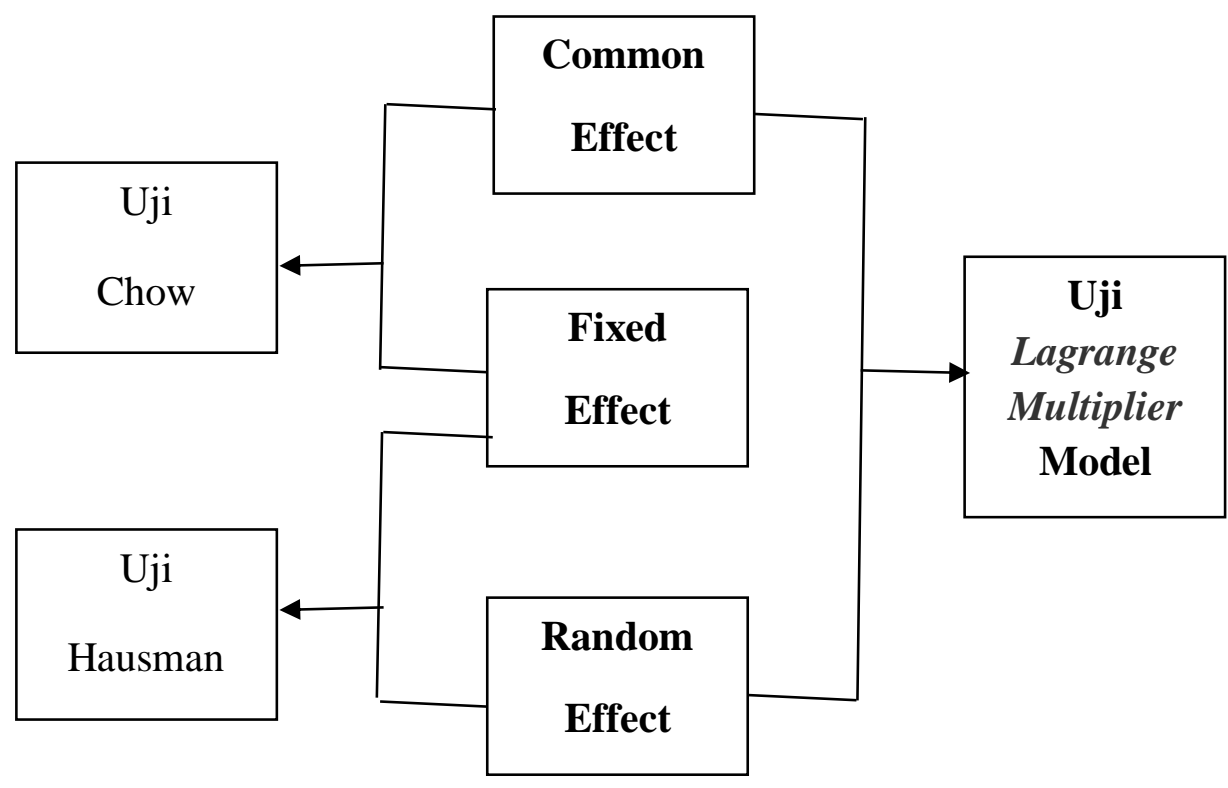

Gambar 2

Proses Pemilihan Model Dalam Data Panel

\section{- Uji Asumsi Klasik}

Uji asumsi klasik terdiri dari uji normalitas, uji multikolinearitas, uji autokorelasi, dan uji heteroskedasitas. Menurut Greene (2011), dalam analisis data panel, uji normalitas dan uji multikolinearitas harus terpenuhi. Apabila belum terpenuhi perlu dilakukan transformasi data.

\section{Normalitas}

Uji normalitas pada model regresi bertujuan untuk menguji residual terdistribusi secara normal atau tidak. Jadi dalam hal ini yang di uji normalitas bukan pada masing-masing variabel independen dan dependen tapi nilai residu yang dihasilkan dari model regresi. Model regresi yang baik adalah memiliki nilai residu yang terdistribusi secara normal (Priyatno, 2011). Salah satu metode yang banyak digunakan untuk menguji normalitas adalah dengan uji Jarque-Bera. Hipotesis yang digunakan adalah:

Ho : Data berdistribusi normal

$\mathrm{H}_{\mathrm{a}}$ : Data tidak berdistribusi normal

Untuk mengetahui suatu data berdistribusi normal univariat dapat digunakan uji Jarque-Bera. Uji Jarque-Bera adalah salah satu metode untuk menguji tingkat kenormalan data. Jika hasil uji Jarque-Bera $<0,05$ maka tidak berdistribusi normal, dan jika sebaliknya maka data berdistribusi normal.

\section{Multikolinearitas}

Menurut Ghozali (2013), uji multikolinearitas bertujuan untuk menguji apakah model regresi ditemukan adanya korelasi antar variabel bebas (independen). Metode yang dapat digunakan untuk menguji terjadinya multikolinieritas dapat dilihat dari matrik korelasi variabel-variabel bebas. Pada matrik korelasi, jika antar variabel bebas terdapat korelasi yang cukup tinggi (umumnya di atas 0,90), maka hal ini merupakan indikasi adanya multikolinieritas. Selain itu dapat juga dilihat nilai 
tolerance dan Variance Inflation Factor $(V I F)$. Batas dari nilai tolerance adalah $\leq 10$ (Ghozali, 2013).

\section{Uji Heteroskedastisitas}

Uji heteroskedastisitas bertujuan untuk menguji apakah dalam model regresi terjadi ketidaksamaan variansi dari residual satu pengamatan ke pengamatan lain (Ghozali, 2013). Pengujian heteroskedastisitas dilakukan dengan menggunakan uji Glejser (Ghozali, 2013). Pada uji Glejser, nilai residual absolut diregresi dengan variabel independen. Jika variabel independen signifikan secara statistik mempengaruhi variabel dependen, maka terdapat indikasi terjadi heteroskedasitas. Uji heteroskedastisitas digunakan untuk melihat apakah residual dari model yang terbentuk memiliki varian yang konstan atau tidak. Suatu model yang baik adalah model yang memiliki varian bebas dari setiap gangguan atau residualnya konstan (homokedastisitas). Sehingga hipotesis yang digunakan untuk pengujian heteroskedastisitas yaitu:

\section{$\mathrm{H}_{0}$ : Homokedastisitas}

$\mathrm{H}_{\mathbf{a}}$ : Heteroskedastisitas

Metode yang digunakan untuk mendeteksi heteroskedastisitas dalam penelitian ini adalah dengan menggunakan White Heteroskedasticity Test pada consistent standard error and covariance. Ketentuan dalam uji heteroskedastisitas yaitu: probabilitas $<$ Alpha (0.05), $\mathrm{H}_{0}$ ditolak, $\mathrm{H}_{\mathbf{1}}$ diterima. Probabilitas $>$ Alpha (0.05), $\mathrm{H}_{\mathbf{1}}$ ditolak, $\mathrm{H}_{0}$ diterima.

\section{Uji Autokorelasi}

Uji autokorelasi bertujuan menguji apakah dalam model regresi linear ada korelasi antara kesalahan pengganggu pada periode t dengan kesalahan pengganggu pada periode t-1 (sebelumnya) (Ghozali, 2013). Autokorelasi muncul karena observasi yang berurutan sepanjang waktu berkaitan satu sama lainnya. Hal ini sering ditemukan pada data runtut waktu (time series) karena "gangguan" pada seseorang individu atau kelompok cenderung mempengaruhi "gangguan" pada individu atau kelompok yang sama pada periode berikutnya. Dalam penelitian ini, peneliti menggunakan pendekatan Durbin Waston ( $D W$ test), karena sampel yang digunakan di bawah 100. Sedangkan, jika sampel diatas 100 maka harus menggunakan pendekatan Lagrange Multiplier (LM test). Uji Durbin-Woston hanya digunakan untuk autokorelasi tingkat satu dan mensyaratkan adanya konstanta dalam model regresi dan tidak ada variabel lag diantara variabel independen (Ghozali, 2013). Uji autokorelasi digunakan untuk mengetahui ada atau tidaknya penyimpanganpenyimpangan asumsi klasik autokorelasi yaitu korelasi yang terjadi antara residual pada suatu pengamatan dengan pengamatan lainnya pada model regresi. Syarat yang harus dipenuhi adalah tidak adanya autokorelasi dalam model regresi. Metode pengujian yang sering digunakan adalah dengan uji Durbin-Watson ( $D W$ test $)$. Selain menggunakan uji Durbin Watson, pengujian autokorelasi juga dapat dilakukan dengan Breusch-Godfrey Serial Correlation LM Test. Sehingga hipotesis yang digunakan untuk pengujian autokorelasi yaitu:

$\mathrm{Ho}_{0}$ : Tidak ada masalah autokorelasi

$\mathrm{H}_{\mathrm{a}}$ : Ada masalah autokorelasi

Probabilitas < Alpha (0.05), Ho ditolak, $\mathrm{H}_{\mathbf{a}}$ diterima.

Probabilitas > Alpha (0.05), $\mathrm{H}_{\mathrm{a}}$ ditolak, $\mathrm{H}_{0}$ diterima. 


\section{HASIL DAN PEMBAHASAN}

\section{Analisis Uji Statistik Deskriptif}

Metode statistik deskriptif adalah statistik yang digunakan untuk menganalisis data dengan cara mendeskripsikan atau menggambarkan data yang telah terkumpul sebagaimana adanya tanpa bermaksud membuat kesimpulan yang berlaku untuk umum atau generalisasi. Statistik deskriptif merupakan analisis data yang menggambarkan data/variabel yang akan digunakan dalam suatu penelitian. Dalam penelitian ini, statistik deskriptif yang digunakan meliputi, nilai minimum maksimum, mean dan standar deviasi (Ghozali, 2016). Gambaran umum dari data yang digunakan yaitu meliputi pengaruh investasi, kas, hutang terhadap arus kas pada perusahaan sektor Consumer Goods di Indonesia yang Go Public pada tahun 2014-2018.

Deskripsi variabel penelitian menggunakan pendekatan analisi deskriptif untuk mengentahui karateristik sampel yang digunakan di dalam penelitian ini melitputi: jumlah sampel (n), rata-rata sampel (mean), nilai maksimum, nilai minimum, serta standar deviasi untuk masing-masing variabel. Tabel di bawah ini menunjukkan statistik deskriptif atas variabel-variabel yang ada pada pemodelan panel data penelitian.

Tabel 3. Statistik Deskriptif

Sumber : Eviews 11.0 (Lihat Lampiran)

\begin{tabular}{lrrrr}
\hline & \multicolumn{1}{c}{ ARUSKAS } & KAS & \multicolumn{1}{l}{ HUTANG } & \multicolumn{1}{c}{ INVESTASI } \\
\hline Mean & 23.31836 & 21.78776 & 23.70413 & 22.14536 \\
\hline Median & 25.259 & 24.26 & 26.414 & 24.82 \\
\hline Maximum & 29.045 & 28.55 & 30.078 & 29.8 \\
\hline Minimum & 12.458 & 5.2 & 12.25 & 6.49 \\
\hline Std. Dev. & 4.720955 & 5.941269 & 5.381275 & 5.585527 \\
\hline
\end{tabular}

Nilai rata-rata (mean) untuk arus kas sebesar 23.31836, minimum 12.458, nilai maximum 29.045, standar deviasi 4.720955. Nilai rata-rata (mean) untuk kas sebesar 21.78776, minimum 5.2, nilai maximum 28.55, standar deviasi 5.941269. Nilai rata-rata (mean) untuk hutang sebesar 23.70413, minimum 12.25, nilai maximum 30.078, standar deviasi 5.381275. Nilai rata-rata (mean) untuk investasi sebesar 22.14536, minimum 6.49, nilai maximum 29.8, standar deviasi 5.585527 .

\section{Uji Analisa Data}

\section{Uji Koefisien Determinasi $\left(R^{2}\right)$}

Uji ini bertujuan untuk menentukan proporsi atau persentase total variasi dalam variabel terikat yang diterangkan oleh variabel bebas. Apabila analisis yang digunakan adalah regresi sederhana, maka yang digunakan adalah nilai $R$ Square. Namun, apabila analisis yang digunakan adalah regresi bergenda, maka yang digunakan adalah Adjusted $R$ Square. Hasil perhitungan Adjusted $R^{2}$ dapat dilihat pada output Model Summary.

Pada kolom Adjusted $R^{2}$ dapat diketahui berapa persentase yang dapat dijelaskan oleh variabelvariabel bebas terhadap variabel terikat. Sedangkan sisanya dipengaruhi atau dijelaskan oleh variabel-variabel lain yang tidak dimasukkan dalam model penelitian. Analisis determinasi dalam regresi linear berganda digunakan untuk mengetahui presentase pengaruh variabel independen secara serentak terhadap variabel dependennya. 
$R$ Square merupakan angka yang berkisar antara 0 sampai 1 yang mengindikasikan besarnya kombinasi variabel independen secara bersama-sama mempengaruhi nilai variabel dependen. Semakin mendekati angka satu, model yang dikeluarkan oleh regresi tersebut akan semakin baik.

\section{a. Uji Chow (Least Square vs Fixed Effect)}

Common model secara umum mendeskripsikan fenomena yang ada. Secara umum, fixed model memberikan informasi yang spesifik atas hubungan yang terjadi antara masingmasing individu pada cross-section. Dengan software Eview 8.1 dapat kita lakukan uji Chow untuk menentukan apakah model yang terbaik untuk digunakan menggunakan Common Effect Model atau Fixed Effect Model dengan hipotesis sebgai berikut :

$\mathrm{H}_{0} \quad$ : Pooled Least Square (Common) Effect

$\mathrm{H}_{\mathrm{a}} \quad$ : Fixed Effect Model

Jika $p$-value $0,000<0,05$ maka metode Fixed Effect lebih baik untuk mengestimasi data panel. Dari hasil redundant Fixed Effect didapatkan hasil p-value 0,0000 < 0,05, sehingga, $\mathrm{H}_{0}$ ditolak dan $\mathrm{H}_{\mathrm{a}}$ diterima, artinya model mengikuti Fixed Effect, karena model Fixed Effect lebih baik daripada Common Effect.

\section{b. Uji Hausman}

Uji Hausman dilakukan utuk menetapkan model yang digunakan apakah Fixed Effect atau Random Effect. Hipotesis yang diajukan adalah :

Ho : Model mengikuti REM

$\mathrm{H}_{\mathrm{a}} \quad$ : Model mengikuti FEM

Probabilitas pada uji Hausman menunjukkan nilai chi-square tidak signifikan secara stastistik, karena 4,400 > 9,487, Jika chi square hitung > chi square tabel maka model yang lebih baik adalah Fixed Effect.

\section{c. Analisis Regresi Data Panel}

Metode Fixed Effect Model (FEM) merupakan salah satu metode regresi data panel. Untuk Fixed Effect Model (FEM), intersep dianggap sebagai variable acak yang mempunyai nilai rata-rata. Intersep dianggap tidak konstan. Koefisien determinasi $\left(R^{2}\right)$ adalah suatu indikator yang digunakan untuk menggambarkan berapa banyak variasi yang dijelaskan dalam model. Berdasarkan nilai $R^{2}$ dapat diketahui tingkat signifikansi atau kesesuaian hubungan antara variabel bebas dan variabel tak bebas dalam regresi linier. Hasil uji ini menunjukkan bahwa secara simultan variabel pengaruh investasi, kas dan hutang terhadap arus kas. Sesuai dengan hasil uji Chow, Hausman, dan LM maka model terbaik adalah Fixed Effect Model (FEM) dengan efek individu/cross section. Dengan demikian, dapat dinyatakan bahwa model regresi membolehkan perbedaan untuk masing-masing individu atau cross section memiliki karakteristik khusus. 


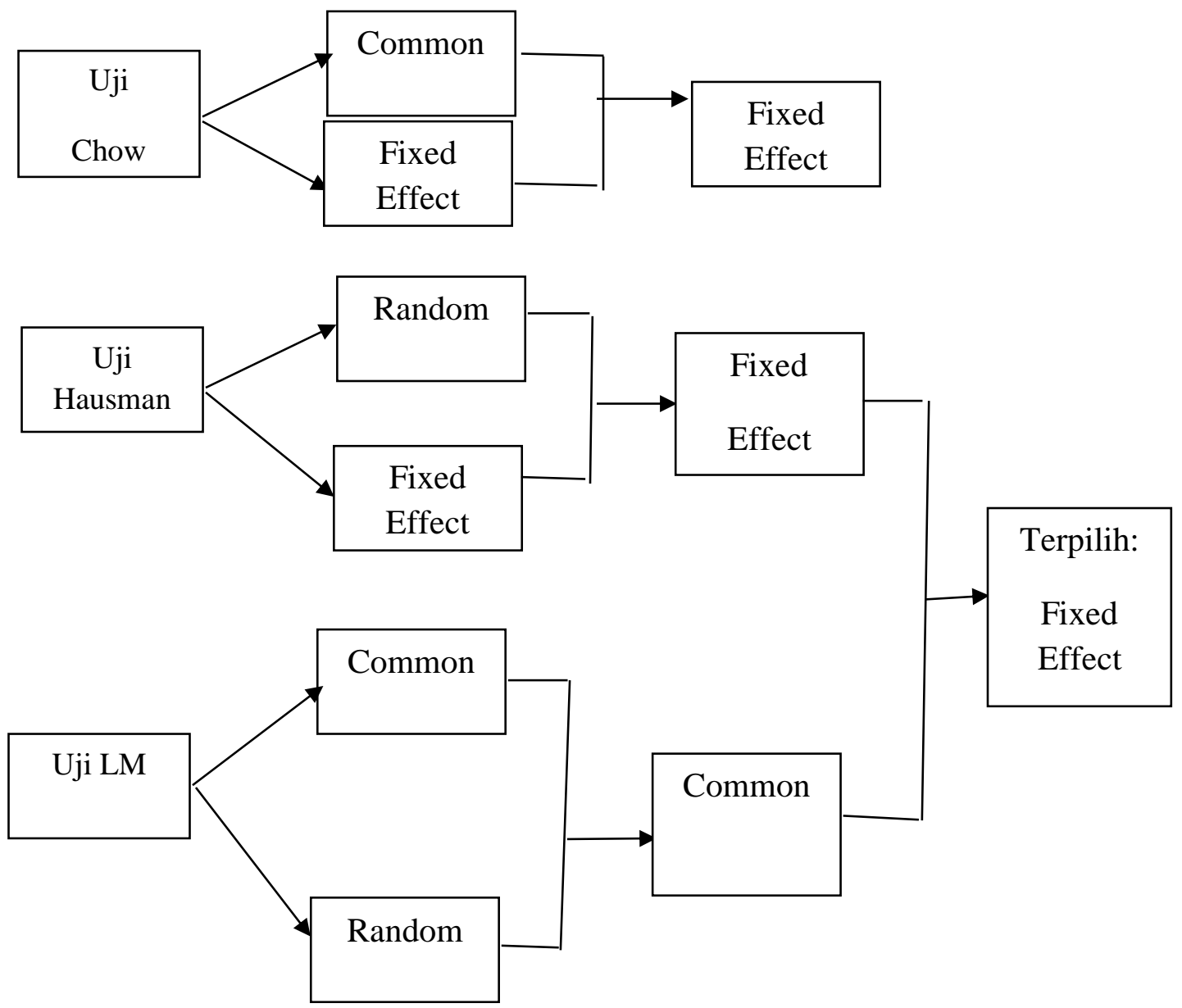

Gambar 3

Uji Berpasangan

\section{d. Pengujian Pengaruh Parsial}

Setelah berhasil diidentifikasi bahwa model yang dipilih adalah Fixed Effect bedasarkan uji Hausman, maka selanjutnya model pengaruh investasi, kas dan hutang terhadap arus kas pada perusahaan sektor Consumer Goods di Indonesia yang Go Public pada tahun 20142018 yang digunakan untuk menjawab hipotesis yang diajukan adalah metode Fixed Effect. Hasil pengujian hipotesis selanjutnya diuraikan sebagai berikut :

Tabel 4. Pengujian Model Parsial Sumber: Eviews 11.0 (Lihat Lampiran)

\begin{tabular}{lccc}
\hline \multicolumn{1}{c}{ Variabel } & Standardized Coefficient Beta & Prob. & Keterangan \\
\hline Investasi > Arus Kas & 0.142515 & 0.0410 & Berpengaruh positif \\
\hline Kas > Arus Kas & 0.149212 & 0.0080 & Berpengaruh positif \\
\hline Hutang > Arus Kas & 0.692003 & 0.0000 & Berpengaruh positif \\
\hline
\end{tabular}

\section{Pembahasan Hasil Penelitian}

\section{Hipotesis 1:}

Hipotesis pertama menguji bahwa investasi berpengaruh terhadap arus kas, dan hipotesis alternatif (Ha) yang dibentuk sebagai berikut:

$\mathrm{Ha}_{1}$ : Investasi berpengaruh terhadap arus kas. 
Berdasarkan Tabel 4 di atas menunjukkan pengujian hipotesis 1 dimana dengan nilai signifikan sebesar 0.0410 dan nilai Standardized Coefficient Beta 0.142515 maka keputusannya $\mathrm{H}_{1}$ didukung. Artinya, investasi berpengaruh positif terhadap arus kas. Hal yang sama juga dilaporkan oleh Kirch dan Terra (2019) dimana sensitivitas investasi terhadap arus kas positif. Ini juga menunjukkan adanya konsistensi terhadap teori dan penelitian Rinofah (2018) yang menjelaskan bahwa perusahaan akan mengutamakan sumber internal untuk membiayai investasi mereka karena biayanya relatif lebih murah daripada sumber eksternal. Meskipun pada umumnya ketersediaan sumber dana internal ini umumnya lebih terbatas dibanding sumber eksternal. Dari nilai koefisien terlihat cash holding memiliki kontribusi lebih besar daripada cash flow karena cash holding ini selain melibatkan arus kas juga melibatkan sekuritas lain yang dapat diubah menjadi kas dalam waktu singkat (marketable securities).

\section{Hipotesis 2:}

Hipotesis kedua menguji bahwa kas berpengaruh terhadap arus kas, dan hipotesis alternatif (Ha) yang dibentuk sebagai berikut:

$\mathrm{Ha}_{2}$ : Kas berpengaruh terhadap arus kas.

Berdasarkan Tabel 4 di atas menunjukkan pengujian hipotesis 2 dimana dengan nilai signifikan sebesar 0.0080 dan nilai Standardized Coefficient Beta 0.149212 maka keputusannya $\mathrm{H}_{2}$ didukung. Artinya, kas berpengaruh positif terhadap arus kas. Hal ini sesuai dengan penelitian sebelumnya (Kirch \& Terra, 2019) dimana sesitivitas kas terhadap arus kas adalah signifikan positif dengan signifikansi $1 \%$. Kusnadi \& Wei (2011) juga melaporkan hal yang sama yaitu sensivitas arus kas terhadap kas adalah positif untuk grup perusahaan yang terkendala keuangan maupun tidak terkendala keuangan.

\section{Hipotesis 3:}

Hipotesis ketiga menguji bahwa hutang berpengaruh terhadap arus kas, dan hipotesis alternatif (Ha) yang dibentuk sebagai berikut:

$\mathrm{Ha}_{3}$ : Utang berpengaruh terhadap arus kas.

Berdasarkan Tabel 4 di atas menunjukkan pengujian hipotesis 3 dimana dengan nilai signifikan sebesar 0.0000 dan nilai Standardized Coefficient Beta 0.692003 maka keputusannya $\mathrm{H}_{3}$ didukung. Artinya, hutang berpengaruh positif terhadap arus kas. Hal ini berbeda dengan penelitian sebelumnya (Kirch \& Terra, 2019) dimana arus kas mempunyai koefisien negatif yang signifikan pada $1 \%$ untuk grup yang terkendala keuangan (financial constraint firm) dan grup yang tidak terkendala keuangan (financial unconstraint firm). Ini disebabkan karena sampel perusahaan yang diambil hanya pada sektor consumer goods. Sedangkan pada jurnal utama, sampel yang diambil berasal dari banyak negara. Hutang pun dapat berpengaruh positif terhadap arus kas jika utang tersebut digunakan dengan baik. Misalnya pada leverage keuangan, jika perusahaan dapat mengelola hutang dengan baik maka akan meningkatkan arus kas.

\section{KESIMPULAN DAN SARAN}

Berdasarkan penelitian yang telah dilakukan dengan metode regresi data panel dan uji individu (uji t) disimpulkan bahwa:

1. Investasi berpengaruh terhadap arus kas.

2. Kas berpengaruh terhadap arus kas.

3. Hutang berpengaruh terhadap arus kas. 
Saran-saran yang dapat diberikan untuk penelitian selanjutnya antara lain:

1. Penelitian tidak hanya dilakukan pada perusahaan sektor consumer goods tetapi dapat meneliti perusahaan di sektor yang berbeda.

2. Penelitian ini dapat meneliti pengaruh investasi, kas dan hutang terhadap arus kas dengan program lainnya seperti SPSS versi 21.

\section{Ucapan Terima Kasih}

Terima kasih penulis ucapkan kepada Prof. Farah Margaretha Leon atas bimbingannya selama kelas Riset Manajemen Keuangan.

\section{REFERENSI}

Agliardi, E., Agliardi, R., \& Spanjers, W. (2016). Corporate financing decisions under ambiguity: Pecking order and liquidity policy implications. Journal of Business Research, 69, 6012-6020.

Almeida, H., Campello, M., \&Weisbach, M. S. (2011). Corporate financial and investment policies when future financing is not frictionless. Journal of Corporate Finance, 17, 675693.

Baños-Caballero, S., García-Teruel, P. J., \& Martínez-Solano, P. (2014). Working capital management, corporate performance, and financial constraints. Journal of Business Research, 67, 332-338.

Chang, X., Dasgupta, S., Wong, G.,\& Yao, J. (2014). Cash-flow sensitivities and the allocation of internal cash flow. Review of Financial Studies, 27, 3628-3657.

Dasgupta, S., Noe, T. H., \& Wang, Z. (2011). Where did all the dollars go? The effect of cash flows on capital and asset structure. Journal of Financial and Quantitative Analysis, 46, 1259-1294.

Dong, Ming., D. H. dan S. H. T. (2015). Stock Market Misvaluation and Corporate Investment. MPRAPaper, (66085).

Francis, B., Hasan, I., Song, L., \& Waisman, M. (2013). Corporate governance and investmentcash flow sensitivity: Evidence from emerging markets. Emerging Markets Review, 15, 57-71.

Kirch, G., \& Terra, P. R. (2019). Financial constraints and the interdependence of corporate financial decisions. RAUSP Management Journal. https://doi.org/10.1108/rausp-01-20190003

Kusnadi, Y. \& Wei, K. C. J. (2011). The determinants of corporate cash management policies: Evidence From around the world. Journal of Corporate Finance, 17, 725-740.

Rinofah. 2018. Cash flow, cash holding, financial constraint and investment in Indonesia. Fakultas Ekonomi Universitas Sarjana Wiyata Tamansiswa Yogyakarta. 